\title{
PENGARUH VARIASI KONSENTRASI UREA TERHADAP FOTOAKTIVITAS MATERIAL FOTOKATALIS N/TiO 2 UNTUK PENJERNIHAN LIMBAH BATIK TENUN IKAT KEDIRI
}

\author{
Aulia Dewi Rosanti*, Anggita R.K Wardani, Eva Umi Latifah \\ Program Studi Kimia, Universitas Islam Kadiri, Kediri \\ *email: aulia.dewi.r@uniska-kediri.ac.id
}

Received 11 February 2020

Accepted 14 May 2020

\begin{abstract}
Abstrak
Fotokatalis merupakan suatu proses transformasi senyawa kimia yang dibantu oleh adanya material katalis dan cahaya. Teknologi fotokatalis sering digunakan untuk mengolah air polutan maupun limbah pewarna tekstil. Pembuatan kain pada industri tenun ikat di Bandar Kidul-Kediri menggunakan pewarna sintetis yang menghasilkan limbah sehingga dapat mencemari lingkungan. Pada penelitian ini telah disintesis $\mathrm{N} / \mathrm{TiO}_{2}$ menggunakan metode wet impregnation (impregnasi basah) untuk menjernihkan limbah batik tenun Kediri. Sintesis dilakukan dengan mereaksikan $\mathrm{TiO}_{2}$ yang dilarutkan ke dalam Aqua DM dan urea dengan variasi konsentrasi 1;2;3;4;5\%(b/b)(N/Ti). Berdasarkan hasil karakterisasi diketahui bahwa semakin besar konsentrasi urea yang ditambahkan, material $\mathrm{N} / \mathrm{TiO}_{2}$ yang dihasilkan memiliki ukuran kristal dan band gap(Eg) yang semakin kecil. Selain itu, permukaan yang dihasilkan pada $\mathrm{N} / \mathrm{TiO}_{2} 5 \%(\mathrm{~b} / \mathrm{b})$ lebih teratur atau homogen apabila dibandingkan dengan $\mathrm{TiO}_{2}$ undoped. . Berdasarkan hasil uji aktifitas fotokatalis $\mathrm{N} / \mathrm{TiO}_{2}$ terhadap limbah batik tenun diketahui bahwa material katalis dengan hasil limbah paling jernih adalah material dengan konsentrasi urea paling besar, yaitu $\mathrm{N} / \mathrm{TiO}_{2} 5 \%(\mathrm{~b} / \mathrm{b})$. Hal ini menunjukkan bahwa semakin besar konsentrasi yang ditambahkan maka fotoaktivitas yang dihasilkan akan semakin besar
\end{abstract}

Kata Kunci: Fotokatalis; $\mathrm{TiO}_{2} ; \mathrm{N} / \mathrm{TiO}_{2}$; Limbah batik tenun ikat.

\begin{abstract}
Photocatalyst is a process transformation of chemical compounds under UV irradiation in the presence of catalyst material. Photocatalyst technology is often used to treat pollutant water or textile waste. The fabric making in the Tenun ikat industry in Bandar Kidul-Kediri uses synthetic dyes which produce waste which can pollute the environment. The effect of variations of concentration of urea on synthesis of $\mathrm{N} / \mathrm{TiO}_{2}$ material by wet impregnation in order to purify the batik weaving waste in Kediri had been studied. The synthesis of $\mathrm{N} / \mathrm{TiO}_{2}$ was done by mixing $\mathrm{TiO}_{2}$ in aqua $\mathrm{DM}$ and urea with the variation of concentration 1,2,3,4 and $5 \%(\mathrm{w} / \mathrm{w})(\mathrm{N} / \mathrm{Ti})$. Based on the characterization results, it is known that the more concentration of urea added, the $\mathrm{N} / \mathrm{TiO}_{2}$ material has a smaller crystal size and a smaller band gap (Eg). In addition, the surface produced at $\mathrm{N} / \mathrm{TiO}_{2} 5 \%(\mathrm{w} / \mathrm{w})$ is more even or homogeneous when compared to undoped $\mathrm{TiO}_{2}$. Based on the results of the $\mathrm{N} / \mathrm{TiO}_{2}$ photocatalyst activity test on woven batik waste, it is known that the catalyst material with the clearest waste results is the material with the highest urea concentration, which is $\mathrm{N} / \mathrm{TiO}_{2} 5 \%(\mathrm{w} / \mathrm{w})$. This shows that the more concentration added the greater the photoactivity produced.
\end{abstract}

Key words: Photocatalyst; $\mathrm{TiO}_{2} ; \mathrm{N} / \mathrm{TiO}_{2}$; woven batik waste. 


\section{Pendahuluan}

Bandar Kidul Kediri merupakan desa yang terkenal dengan sebutan kampung wisata tenun ikat dikarenakan desa Bandar Kidul memiliki banyak pengrajin tenun ikat. Tenun Ikat ATBM merupakan singkatan dari Alat Tenun Bukan Mesin. (Condro dan Banindro 2014). Pembuatan Kain Tenun Ikat tidak lepas dengan penggunaan zat pewarna. Zat perwarna yang digunakan dapat berupa zat warna alami maupun zat warna sintetis. Zat warna yang digunakan pada kerajinan tenun ikat di Bandar Kidul adalah zat warna sintetis.

Jenis zat pewarna sintetis yang digunakan terdiri dari cat indigo, cat soga, cat naphtol, cat rapid, cat indanthrene, cat basis, cat proison, indigosol, dan prada (Sari, 2014). Zat warna sintetis merupakan zat warna yang berasal dari zat-zat kimia tertentu. Zat pewarna sintesis sangat berbahaya apabila dibuang ke lingkungan sekitar, disamping mengganggu ekosistem tanah juga dapat mengganggu kehidupan sosial dikarenakan baunya yang menyengat sehingga mengganggu kehidupan masyarakat sekitar (Sitanggang, 2017) (Prastiwi, 2017). Selama ini limbah hasil pewarnaan tenun ikat hanya dibuang dan dikubur di tanah tanpa ada perlakuan lebih lanjut, sehingga sangat mengganggu lingkungan dan masyarakat sekitar.

Salah satu metode penjernihan limbah tekstil adalah dengan menggunakan fotokatalis (Tussa'adah, 2015). Fotokatalis merupakan proses reaksi kimia yang dibantu oleh radiasi sinar UV dan katalis semikonduktor (Agustina et al, 2016; So et al, 2002). Fotokatalis dapat digunakan untuk mengolah air polutan maupun limbah tekstil(Agustina et al, 2016).

Katalis yang sering digunakan sebagai semikonduktor untuk fotokatalis adalah $\mathrm{TiO}_{2}$, dikarenakan $\mathrm{TiO}_{2}$ merupakan bahan kimia yang ramah lingkungan, murah dan mudah didapat(Hoffman et al.
2013; Rosanti 2014). $\mathrm{TiO}_{2}$ mempunyai energy celah pita sebesar 3,2 eV dimana energy celah pita ini berhubungan dengan maksimal serapan panjang gelombang di daerah UV yang bekisar mulai 350-400 $\mathrm{nm}$ sehingga dalam aplikasinya efisiensi pemanfaatan sinar matahari kurang maksimal karena hanya 4-5\% spectra dari sinar matahari berada pada daerah UV, sedangkan $45 \%$ spectra berada di daerah sinar tampak(Garcia et al, 2003; Hu et al. 2007; Rosanti, 2014). Oleh karena itu perlu dilakukan modifikasi material $\mathrm{TiO}_{2}$ untuk mempersempit celah pita sehingga dapat meningkatkan respon terhadap sinar tampak(Rosanti, 2014). Modifikasi material $\mathrm{TiO}_{2}$ dapat dilakukan dengan menambahkan atau mengembankan unsur lain ke dalam $\mathrm{TiO}_{2}$ yang biasa disebut doping(Rosanti, 2014).

Modifikasi semikonduktor $\mathrm{TiO}_{2}$ dapat dilakukan dengan menambahkan unsur lain baik logam maupun non logam(Rosanti, 2014). Doping unsur logam dapat berupa unsur-unsur dari golongan unsur logam transisi yaitu besi $(\mathrm{Fe})$, tembaga $(\mathrm{Cu})$, nikel $(\mathrm{Ni})$, kromium $(\mathrm{Cr})$, kobalt $(\mathrm{Co})$, seng $(\mathrm{Zn})$, vanadium $(\mathrm{V})$, dan mangan (Mn)(Abazović et al. 2009; Rosanti 2014) maupun unsur non logam seperti nitrogen $(\mathrm{N})$, belerang $(\mathrm{S})$, karbon (C), fosfor (P), boron (B), fluor $(\mathrm{F})$, iodin (I), klor $(\mathrm{Cl})$ dan bromin (Br)(Rosanti, 2014; Zaleska, 2008).

Beberapa penelitian yang membuktikan bahwa doping dapat meningkatkan efektivitas dari fotokatalis yaitu penelitian Poluakan et al, 2015 telah berhasil mendegradasi zat warna remazol yellow menggunakan $\mathrm{TiO}_{2}$ doping Karbon Aktif. Berdasarkan penelitian yang telah dilakukan menunjukkan bahwa $\mathrm{TiO}_{2}$ doping karbon aktif mampu mendegradasi remazol yelow dalam jumlah yang lebih banyak dibandingkan $\mathrm{TiO}_{2}$-Zeolit pada beberapa konsentrasi remazol yellow. Prosentase remazol yellow terdegradasi oleh $\mathrm{TiO}_{2}$-zeolit yang tertinggi sebesar 83\% pada konsentrasi awal 20 ppm dan 
untuk $\mathrm{TiO}_{2}$-karbon aktif mampu mendegradasi sampai $95 \%$ pada konsentrasi awal 30 ppm.

Penelitian yang telah dilakukan oleh Wardhani et al (Wardhani, Bahari, and Khunur 2016) tentang aktifitas fotokatalitik beads $\mathrm{TiO}_{2}-\mathrm{N} /$ Zeolit-kitosan pada fotodegradasi metilen biru, menunjukkan bahwa pendopingan $\mathrm{N}$ pada $\mathrm{TiO}_{2}$ dapat menurunkan energi band gap $\mathrm{TiO}_{2}$ dan dengan adanya dopan $\mathrm{N}$ dapat meningkatkan degradasi metilen biru serta dengan ditambahkannya pengemban zeolit lebih meningkatkan degradasi metilen biru.

Pada penelitian ini dilakukan sintesis fotokatalis $\mathrm{N} / \mathrm{TiO}_{2}$ untuk aplikasi ke limbah batik tenun ikat Kediri dengan menggunakan Urea sebagai sumber dari N. Pemilihan Urea sebagai sumber $\mathrm{N}$ (nitrogen) pada penelitian ini sebagai unsur doping dikarenakan urea mampu didapatkan secara mudah di pasaran dan lebih murah sehingga dapat mempermudah pengrajin untuk mendapatkan bahan tersebut. Sedangkan pemilihan unsur $\mathrm{N}$ dikarenakan $\mathrm{N}$ merupakan unsur non logam yang paling efektif karena ukurannya yang tidak jauh berbeda dengan oksigen dan energi ionisasinya yang kecil (Kusumawardani, 2009).

Penelitian ini dilakukan untuk mengetahui pengaruh konsentrasi urea pada sintesis $\mathrm{N} / \mathrm{TiO}_{2}$ menggunakan metode wet impregnation (impregnasi basah) dalam penjernihan limbah batik tenun Kediri. Diharapkan dengan penelitian ini dapat diketahui konsentrasi optimum urea yang diperlukan untuk penjernihan limbah sehingga dapat membantu industri tenun ikat Kediri untuk mengolah limbah tersebut sebelum dibuang ke lingkungan.

\section{Metodologi}

Pada penelitian ini terdiri dari 3 (tiga) tahap yaitu tahap sintesis $\mathrm{TiO}_{2}$ undoped dan $\mathrm{N} / \mathrm{TiO}_{2}$ dengan variasi konsentrasi urea (b/b) serta karakterisasi material.

Karakterisasi material dilakukan dengan menggunakan XRD (X-Ray Diffractometer), DRS UV-Vis(Diffuse Reflectance Spectrophotometer UV-Vis) dan SEM EDX (Spectroscopy Scanning Elektron Microscopy with Energy Dispersive X Ray), tahap terakhir adalah uji aktivitas fotoaktivitas material hasil sintesis terhadap penjernihan limbah pewarna tenun ikat.

\section{Alat dan Bahan}

Bahan yang digunakan dalam penelitian ini adalah aqua DM (Bratachem). Bahan bahan kimia lain yang digunakan diantaranya memiliki kualitas pro analysis dari Merck yaitu $\mathrm{TiO}_{2}$ dan Urea $99 \%$.

Alat yang digunakan pada penelitian ini adalah seperangkat alat gelas laboratorium, pengaduk magnet (magnetic stirrer), aluminium foil, kertas saring Whattman No. 42, timbangan analitik (Ohaus), sentrifuge, Oven (Memmert D06836), Furnace (Thermoscientific), XRD (X-Ray Diffractometer) (X'Pert PRO), Spetrofotometer UV-VIS (Shimadzu 2450, dengan sistem double beam dengan tambahan aksesoris Diffuse Reflectance Spectroscopic), SEM EDX (Spectroscopy Scanning Elektron Microscopy with Energy Dispersive $X$ Ray) (JEOL JED-2300).

\section{Prosedur}

Sintesis $\mathrm{TiO}_{2}$ undoped

Pada sintesis $\mathrm{TiO}_{2}$ undoped dilakukan dengan melarutkan sebanyak 5 gram $\mathrm{TiO}_{2}$ kedalam $50 \mathrm{~mL}$ aqua DM. Larutan diaduk menggunakan pengaduk magnet selama 2 jam dan didiamkan selama 24 jam. Kemudian larutan dipisahkan dengan menggunakan sentrifuge dengan menggunakan kecepatan 2000 rpm selama 1 jam. Padatan yang telah terpisahkan didiamkan selama 24 jam. Kemudian padatan yang diperoleh dioven pada suhu $80^{\circ} \mathrm{C}$ selama 
8 jam dimana pada saat dioven dilakukan penggerusan setiap 1 jam. Serbuk yang diperoleh kemudian dikalsinasi pada temperatur $500^{\circ} \mathrm{C}$ selama 4 jam.

$\begin{array}{llll}\begin{array}{l}\text { Sintesis } \\ \text { konsentrasi }\end{array} & \mathrm{TiO}_{2} & \text { dengan } & \text { variasi } \\ \text { Pada sintesis } & \mathrm{N} / \mathrm{TiO}_{2} & \text { dilakukan }\end{array}$ dengan melarutkan sebanyak 5 gram $\mathrm{TiO}_{2}$ kedalam $50 \mathrm{~mL}$ aqua DM kemudian ditambahkan urea dengan variasi konsentrasi $\quad 1 ; 2 ; 3 ; 4 ; 5 \quad \%(\mathrm{~b} / \mathrm{b})(\mathrm{N} / \mathrm{Ti})$. Larutan campuran diaduk menggunakan pengaduk magnet selama 2 jam dan didiamkan selama 24 jam. Kemudian larutan campuran dipisahkan dengan menggunakan sentrifuge dengan menggunakan kecepatan $2000 \mathrm{rpm}$ selama 1 jam. Padatan yang telah terpisahkan didiamkan selama 24 jam. Kemudian padatan yang diperoleh dioven pada suhu $80^{\circ} \mathrm{C}$ selama 8 jam dimana pada saat dioven dilakukan penggerusan setiap 1 jam. Serbuk yang diperoleh kemudian dikalsinasi pada temperatur $500^{\circ} \mathrm{C}$ selama 4 jam.

Karakterisasi $\mathrm{TiO}_{2}$ undoped dan $\mathrm{N} / \mathrm{TiO}{ }_{2}$ dengan variasi konsentrasi hasil sintesis

Material hasil sintesis dikarakterisasi menggunakan XRD ( $X$ Ray Diffraction), DRS-UV (Diffuse Reflectance Spectrophotometer UV-Vis) dan SEM EDX(Scanning Electron Microscope with Energy Dispersive $X$ Ray). Karakterisasi menggunakan XRD digunakan untuk mengetahui struktur kristal dan ukuran kristal. Struktur kristal dapat diketahui dengan membandingkan antara data JCPDS dari $\mathrm{TiO}_{2}$ dengan difraktogram dari sampel hasil sintesis. Ukuran kristal dapat dihitung menggunakan persamaan Scherer (Rosanti, 2014) :

$$
D=\frac{0,9 \lambda}{\beta \cos \theta}
$$

dimana D merupakan rata-rata ukuran kristal, $\lambda$ adalah panjang gelombang sinar $\mathrm{X}, \theta$ adalah sudut Bragg, serta $\beta$ adalah FWHM (Full Width at Half Maximum) yang merupakan puncak utama dari fase anatase atau fase rutile. Setelah dilakukan karakterisasi menggunakan XRD, material hasil sintesis dikarakterisasi menggunakan DR-UV.

Karakterisasi menggunakan DR-UV digunakan untuk mengetahui pergeseran serapan juga untuk mengetahui besarnya Eg (Energi celah pita). Energi celah pita dapat dihitung menggunakan persamaan Kubelka-Munk (Rosanti, 2014) :

$$
(K h v)^{1 / n}=A(h v-E g)
$$

dimana $\mathrm{h}$ merupakan koefisien planck $=6.34 \times 10^{-34} \mathrm{Js}, \quad \mathrm{v}$ merupakan frekuensi vibrasi, Eg adalah energi celah pita, A adalah konstanta proporsional serta nilai $\mathrm{n}$ menggambarkan jenis semikonduktor, apabila $\mathrm{n}=1 / 2$ maka direct semikonduktor, $\mathrm{n}=2$ maka indirect semikonduktor. Karakterisasi material selanjutnya menggunakan SEM EDX, SEM EDX digunakan selain untuk mengetahui struktur permukaan dari material hasil sintesis, juga untuk mengetahui jumlah unsur $\mathrm{N}$ yang berhasil masuk pada $\mathrm{TiO}_{2}$ (Rosanti, 2014).

\section{Analisa Kejernihan Air Limbah dibawah paparan sinar matahari}

Material hasil sintesis diaplikasikan untuk penjernihan limbah pewarna tenun ikat. Material hasil sintesis diambil sebanyak 1 gram dan dicampurkan dengan $50 \mathrm{~mL}$ limbah pewarna tenun ikat. Larutan campuran kemudian disinari dibawah paparan cahaya matahari selama 5 jam, kemudian larutan campuran disaring menggunakan kertas Whattman No.42. Setelah disaring, dilakukan pengamatan perubahan warna yang terjadi. Pada analisa ini tidak dilakukan secara kuantitatif dikarenakan limbah pewarna yang diambil merupakan limbah pewarna 
campuran sehingga sulit untuk menentukan standar dan panjang gelombang yang digunakan.

\section{Hasil dan Pembahasan}

Karakterisasi material $\quad \mathrm{N} / \mathrm{TiO}_{2}$ menggunakan XRD (X-Ray Diffraction)
Karakterisasi menggunakan XRD bertujuan untuk mengetahui jenis kristal, dan ukuran kristal. Analisis data menggunakan XRD dilakukan dengan membandingkan difraktogram dari N/TiO 2 dengan $\mathrm{TiO}_{2}$ sehingga dapat diperoleh informasi mengenai perubahan struktur sampel akibat penambahan unsur $\mathrm{N}$.

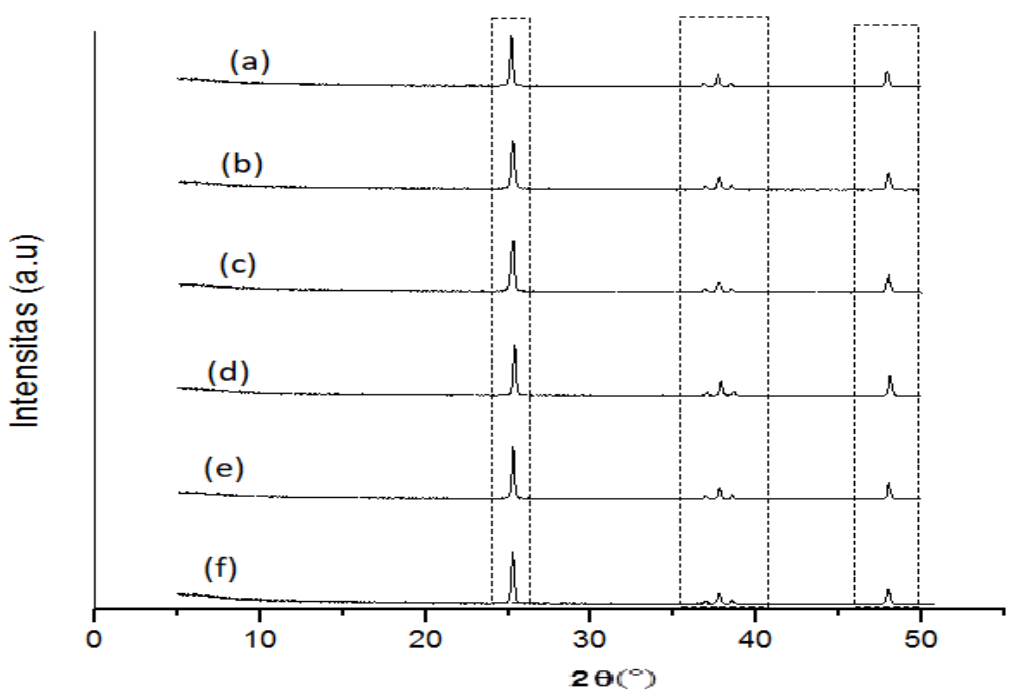

Gambar 1. Difraktogram XRD dari $\mathrm{TiO}_{2}$ (a) dan $\mathrm{N} / \mathrm{TiO}_{2}$ dengan variasi konsentrasi $: 1 \%(\mathrm{~b} / \mathrm{b})(\mathrm{b}) ; 2 \%(\mathrm{~b} / \mathrm{b})(\mathrm{c}) ; 3 \%(\mathrm{~b} / \mathrm{b})(\mathrm{d}) ; 4 \%(\mathrm{~b} / \mathrm{b})(\mathrm{e}) ; 5 \%(\mathrm{~b} / \mathrm{b})(\mathrm{f})$

Hasil Difraktogram pada Gambar 1 dapat dilihat bahwa dengan penambahan konsentrasi urea yang ditambahkan terjadi perbedaan intensitas serapan pada daerah dengan puncak intensitas yang relative tinggi yaitu $2 \theta=25^{\circ}$ puncak ini muncul baik pada $\mathrm{N}-\mathrm{TiO}_{2}$ maupun $\mathrm{TiO}_{2}$ dengan bidang difraksi $\mathrm{d}_{101}(3,5 \AA)$. Pada Gambar 1 terlihat intensitas serapan terlihat menurun pada penambahan konsentrasi $1 \%(\mathrm{~b} / \mathrm{b})$ hingga $2 \%(\mathrm{~b} / \mathrm{b})$ sedangkan pada $3 \%(\mathrm{~b} / \mathrm{b})$ kembali naik dan pada $4 \%(\mathrm{~b} / \mathrm{b})$ hingga $5 \%(\mathrm{~b} / \mathrm{b})$ terlihat menurun sangat tajam. Penurunan intensitas ini juga dapat dilihat pada Tabel 1. Terjadinya penurunan ini dikarenakan metode impregnasi memiliki beberapa kelemahan yaitu sulit untuk mendapatkan homogenitas yang tinggi, sehingga menyebabkan partikel pada kristal mudah mengalami aglomerasi
(Pinna 1998). Terjadinya aglomerasi dapat mempengaruhi intensitas dan ukuran kristal yang dihasilkan, semakin banyak partikel yang mengalami aglomerasi maka ukuran kristal akan semakin besar pula. Pada Tabel 1 dapat dilihat bahwa semakin besar penambahan konsentrasi urea maka ukuran kristal juga akan semakin menurun, kecuali pada penambahan konsentrasi urea sebesar 3\%(b/b). Hal ini disebabkan karena kemungkinan terjadinya aglomerasi sehingga ukuran kristal menjadi besar. Hasil ukuran kristal ini sejalan dengan besarnya intensitas yang terlihat pada difraktogram, sehingga dapat diasumsikan bahwa terjadinya aglomerisasi dapat mempengaruhi intensitas dan ukuran kristal suatu material (Araoyinbo et al, 2018) 
Tabel 1. Ukuran Kristal dari $\mathrm{TiO}_{2}$ dan $\mathrm{N} / \mathrm{TiO}_{2}$ dengan variasi konsentrasi

\begin{tabular}{|c|c|c|c|c|c|}
\hline Material & $\begin{array}{c}\mathbf{d} \\
(\stackrel{\AA}{\mathbf{A}})\end{array}$ & Height(cts) & FWHM & $\begin{array}{c}\text { Ukuran Kristal } \\
(\mathbf{n m})\end{array}$ & $\begin{array}{c}\text { Rata-rata } \\
\text { ukuran } \\
\text { Kristal } \\
\text { (nm) }\end{array}$ \\
\hline \multirow{3}{*}{$\mathrm{TiO}_{2}$} & 3,53997 & 1414,61 & 0,1338 & 10,619 & \multirow{3}{*}{9.482} \\
\hline & 2,38489 & 292,15 & 0,1673 & 8,758 & \\
\hline & 1,89838 & 441,94 & 0,1673 & 9,069 & \\
\hline \multirow{3}{*}{$\begin{array}{l}\mathrm{N} / \mathrm{TiO}_{2} \\
1 \%(\mathrm{~b} / \mathrm{b})\end{array}$} & 3,51900 & 1271,04 & 0,1673 & 8,493 & \multirow{3}{*}{12.995} \\
\hline & 2,38105 & 331,20 & 0,0836 & 17,530 & \\
\hline & 1,89464 & 447,21 & 0,1171 & 12,962 & \\
\hline \multirow{3}{*}{$\begin{array}{l}\mathrm{N} / \mathrm{TiO}_{2} \\
2 \%(\mathrm{~b} / \mathrm{b})\end{array}$} & 3,51742 & 1244,35 & 0,2175 & 6,533 & \multirow{3}{*}{11.880} \\
\hline & 2,38431 & 258,25 & 0,1338 & 10,952 & \\
\hline & 1,89427 & 422,18 & 0,0836 & 18,156 & \\
\hline \multirow{3}{*}{$\begin{array}{c}\mathrm{N} / \mathrm{TiO}_{2} \\
3 \%(\mathrm{~b} / \mathrm{b})\end{array}$} & 3,50693 & 1341,75 & 0,1673 & 8,496 & \multirow{3}{*}{12.020} \\
\hline & 2,37653 & 380,56 & 0,1004 & 14,600 & \\
\hline & 1,89211 & 541,97 & 0,1171 & 12,966 & \\
\hline \multirow{3}{*}{$\begin{array}{c}\mathrm{N} / \mathrm{TiO}_{2} \\
4 \%(\mathrm{~b} / \mathrm{b})\end{array}$} & 3,52361 & 1748,79 & 0,1171 & 12,136 & \multirow{3}{*}{11.829} \\
\hline & 2,38158 & 370,76 & 0,1338 & 10,949 & \\
\hline & 1,89360 & 541,09 & 0,1224 & 12,400 & \\
\hline \multirow{3}{*}{$\begin{array}{c}\mathrm{N} / \mathrm{TiO}_{2} 5 \\
\%(\mathrm{~b} / \mathrm{b})\end{array}$} & 3,52654 & 1076,83 & 0,2007 & 7,079 & \multirow{3}{*}{10.582} \\
\hline & 2,38299 & 253,55 & 0,1004 & 14,592 & \\
\hline & 1,89600 & 309,40 & 0,1506 & 10,075 & \\
\hline
\end{tabular}

Fotoaktivitas dari semikonduktor fotokatalis sangat dipengaruhi oleh luasan permukaan aktifnya, dimana semakin besar ukuran kristal maka luas permukaan aktifnya akan semakin kecil, sehingga menyebabkan fotoaktivitas yang dihasilkan juga akan semakin kecil dan sebaliknya. Berdasarkan hasil perhitungan (Tabel 1) dapat diketahui bahwa ukuran kristal paling kecil yaitu pada material $\mathrm{N} / \mathrm{TiO}_{2} 5 \%(\mathrm{~b} / \mathrm{b}$ ) yaitu sebesar $10,582 \mathrm{~nm}$ sehingga dapat diketahui bahwa fotoaktivitas yang paling besar adalah semikonduktor fotokatalis $\quad \mathrm{N} / \mathrm{TiO}_{2}$ $5 \%(\mathrm{~b} / \mathrm{b})$.
Pengaruh Variasi Konsentrasi pada Responsitivitas $\mathrm{N} / \mathrm{TiO}_{2}$ terhadap sinar tampak

Responsivitas material semikonduktor terhadap sinar tampak diamati menggunakan spektrometer Diffuse Refectance Spectrophotometer $U V$-Visible (DRS-UV) yang dilakukan pada panjang gelombang 200-800 nm. Berdasarkan hasil spektra absorbansi (DRS-UV) dari $\mathrm{TiO}_{2}$ undoped dan $\mathrm{N} / \mathrm{TiO}_{2}$ dengan variasi konsentrasi (Gambar 2) dapat diketahui bahwa semakin besar urea yang ditambahkan maka spektra DRS-UV semakin bergeser ke daerah dengan panjang gelombang yang lebih besar, meskipun pergeseran ini belum berada pada daerah sinar tampak. Pergeseran serapan ke daerah panjang gelombang yang lebih besar pada $\mathrm{N} / \mathrm{TiO}_{2}$ menunjukkan bahwa hasil sintesis dari $\mathrm{N} / \mathrm{TiO}_{2}$ memiliki responsivitas lebih tinggi dibandingkan dengan $\mathrm{TiO}_{2}$. 


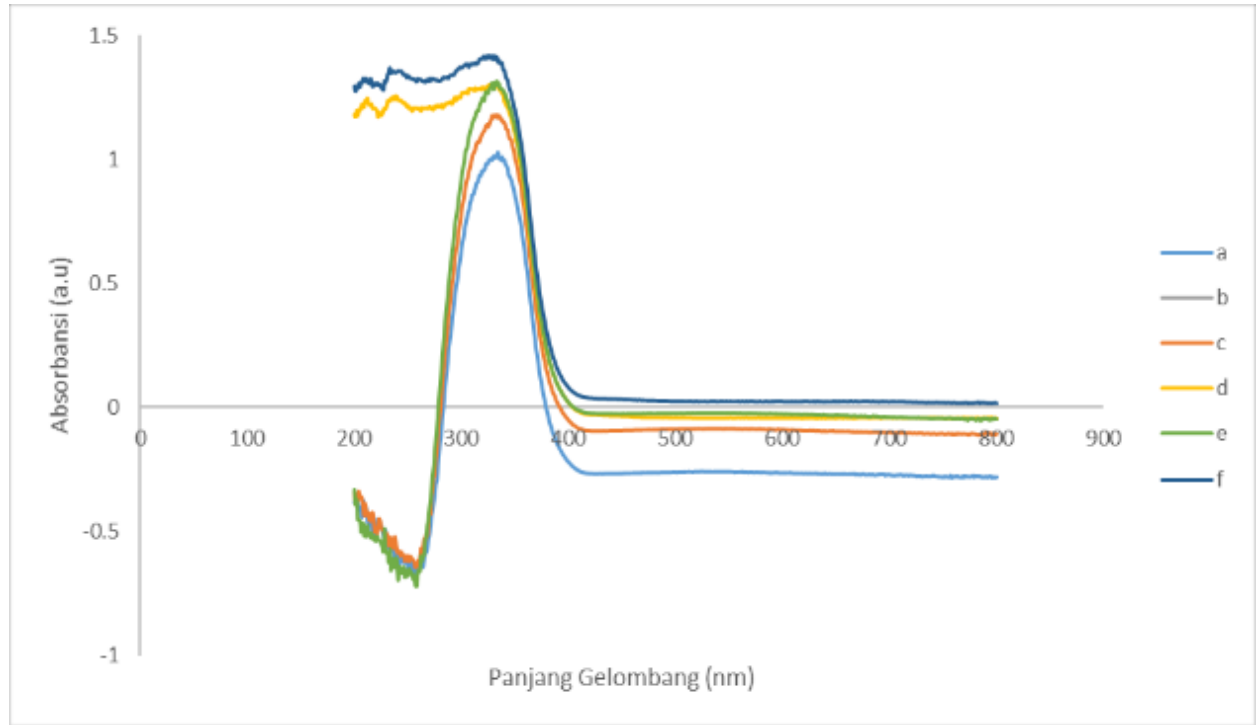

Gambar 2. Spectra DR-UV $\mathrm{TiO}_{2}(\mathrm{a})$ dan $\mathrm{N} / \mathrm{TiO}_{2}$ dengan variasi konsentrasi $: 1 \%(\mathrm{~b} / \mathrm{b})(\mathrm{b}) ; 2 \%(\mathrm{~b} / \mathrm{b})(\mathrm{c}) ; 3 \%(\mathrm{~b} / \mathrm{b})(\mathrm{d}) ; 4 \%(\mathrm{~b} / \mathrm{b})(\mathrm{e}) ; 5 \%(\mathrm{~b} / \mathrm{b})(\mathrm{f})$

Pergeseran yang terjadi disebabkan oleh adanya nitrogen terdoping pada matriks $\mathrm{TiO}_{2}$ dapat mengubah struktur pita elektronik titania dengan menggabungkan orbital $2 p$ nitrogen dan orbital $2 p$ oksigen sehingga efektif memperpendek energi celah pita material secara signifikan dimana mekanisme yang terjadi menurut (Irie et al, 2003) yaitu dengan adanya nitrogen menghasilkan orbital dengan kedudukan baru yang berasal dari orbital $2 \mathrm{p} N$ yang berada diantara pita valensi (orbital 2p O) dengan pita konduksi yang terdiri dari orbital $3 \mathrm{~d}$ Ti)Orbital $2 \mathrm{p}$ dari Nitrogen berperan sebagai loncatan untuk electron di dalam orbital $2 p$ Oksigen sehingga electron ini hanya akan membutuhkan lompatan yang kecil untuk bisa dipromosikan ke pita konduksi. Ketika proses ini ini tejadi electron dari pita valensi asal dapat bermigrasi ke level energy tengah dan meninggalkan hole di pita valensi(Kusumawardani 2009).

Energi celah pita (Eg) dihitung menggunakan persamaan Kubelka-Munk dimana persamaan ini menggunakan persamaan Tauc yang kemudian disubstitusi dengan koefisien KubelkaMunk(Rosanti 2014). Berdasarkan hasil XRD bahwa fasa yang terbentuk pada sintesis $\mathrm{TiO}_{2}$ dan $\mathrm{N} / \mathrm{TiO}_{2}$ adalah fasa anatase, sehingga nilai $\mathrm{n}$ yang digunakan untuk menentukan energi celah pita adalah 2(dua). Hal ini dikarenakan $\mathrm{TiO}_{2}$ dengan fasa anatase merupakan indirect semikonduktor. Hasil perhitungan nilai $E g$ dari $\mathrm{TiO}_{2}$ dan $\mathrm{N} / \mathrm{TiO}_{2}$ hasil sintesis dengan menggunakan persamaan Kubelka-Munk dapat dilihat pada Tabel 2 .

Semakin besar konsentrasi urea maka akan semakin banyak $\mathrm{N}$ yang akan masuk ke dalam kisi kristal $\mathrm{TiO}_{2}$, sehingga dengan bertambahnya konsentrasi $\mathrm{N}$ maka nilai Eg akan semakin menurun. Apabila dibandingkan dengan $\mathrm{TiO}_{2}, \quad \mathrm{~N} / \mathrm{TiO}_{2}$ dengan konsentrasi $5 \%(\mathrm{~b} / \mathrm{b})$ mempunyai nilai $E g$ yang lebih sempit yaitu $3,210 \mathrm{eV}$, maka dapat diasumsikan bahwa $\mathrm{N}$ berhasil masuk ke dalam kisi kristal $\mathrm{TiO}_{2}$. Adanya pergeseran serapan dan nilai $E g$ yang lebih sempit pada $\mathrm{N} / \mathrm{TiO}_{2}$ menunjukkan bahwa proses penyisipan $\mathrm{N}$ pada kisi kristal $\mathrm{TiO}_{2}$ dapat meningkatkan responsivitas pada sinar tampak.

Berdasarkan nilai $E g \quad$ yang didapatkan, maka dapat dihitung pula nilai $\lambda$ tepi dimana serapan tepi berbanding terbalik dengan nilai $E g$. Semakin sempit nilai $E g$ maka $\lambda$ tepi akan semakin besar. Pada Tabel 2. 
menunjukkan bahwa pada $\mathrm{TiO}_{2}$ memiliki serapan tepi sebesar $377,41 \mathrm{~nm}$ dan semakin besar konsentrasi urea yang ditambahkan pada material $\mathrm{N} / \mathrm{TiO}_{2}$ maka serapan tepi yang dihasilkan akan semakin bergeser kearah panjang gelombang yang lebih besar. Dari hasil analisa yang telah dilakukan dapat diasumsikan bahwa material $\mathrm{N} / \mathrm{TiO}_{2}$ $5 \%(\mathrm{~b} / \mathrm{b})$ memiliki responsitifitas terhadap sinar tampak paling tinggi karena dapat menggeser serapan tepi hingga 387,03 nm dengan nilai $E g$ sebesar 3,21 eV.

Tabel 2. Energi Celah Pita $(E g) \mathrm{TiO}_{2}$ dan $\mathrm{N} / \mathrm{TiO}_{2}$ dengan variasi konsentrasi

\begin{tabular}{lll}
\hline Material & $\boldsymbol{E g}(\mathbf{e V})$ & $\lambda$ tepi (nm) \\
\hline $\mathrm{TiO}_{2}$ & 3,292 & 377,41 \\
$\mathrm{~N} / \mathrm{TiO}_{2} 1 \%(\mathrm{~b} / \mathrm{b})$ & 3,257 & 381,48 \\
$\mathrm{~N} / \mathrm{TiO}_{2} 2 \%(\mathrm{~b} / \mathrm{b})$ & 3,248 & 382,49 \\
$\mathrm{~N} / \mathrm{TiO}_{2} 3 \%(\mathrm{~b} / \mathrm{b})$ & 3,228 & 384,78 \\
$\mathrm{~N} / \mathrm{TiO}_{2} 4 \%(\mathrm{~b} / \mathrm{b})$ & 3,220 & 385,79 \\
$\mathrm{~N} / \mathrm{TiO}_{2} 5 \%(\mathrm{~b} / \mathrm{b})$ & 3,210 & 387,03 \\
\hline
\end{tabular}

Pengaruh Variasi Konsentrasi terhadap struktur permukaan material hasil sintesis.

Berdasarkan hasil karakterisasi material sebelumnya diketahui bahwa material yang mempunyai karakter paling optimum yaitu ukuran kristal paling kecil dan Eg yang sempit adalah pada material $\mathrm{N} / \mathrm{TiO}_{2} 5 \%(\mathrm{~b} / \mathrm{b})$, sehingga pada analisa SEM EDX hanya dilakukan pada material $\mathrm{TiO}_{2}$ undoped dan $\mathrm{N} / \mathrm{TiO}_{2} 5 \%(\mathrm{~b} / \mathrm{b})$. Hal ini dilakukan untuk membandingkan karakter material $\mathrm{TiO}_{2}$ undoped dan $\mathrm{N} / \mathrm{TiO}_{2} \quad 5 \%(\mathrm{~b} / \mathrm{b})$ menggunakan SEM EDX.

Analisis material $\mathrm{TiO}_{2}$ undoped dan $\mathrm{N} / \mathrm{TiO}_{2} 5 \%(\mathrm{~b} / \mathrm{b})$ menggunakan SEM EDX dilakukan untuk mengetahui morfologi, homogenitas padatan yang telah disintesis dan berapa banyak unsur $\mathrm{N}$

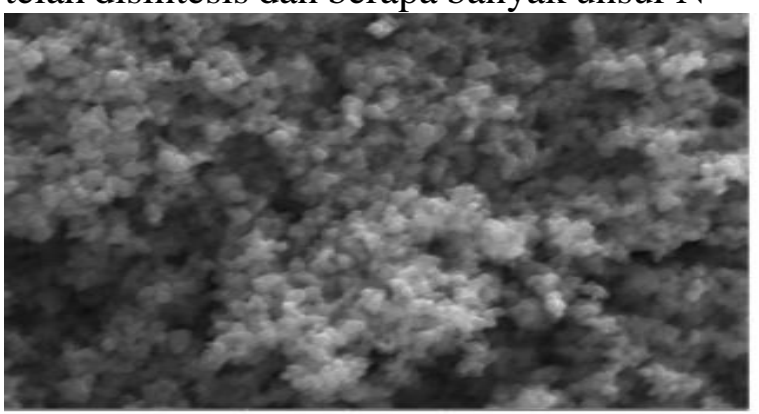

(a) yang berada pada permukaan maupun yang berada di dalam kisi Kristal. Selain itu, dengan menggunakan SEM juga dapat mengetahui pori- pori dari material yang telah disintesis karena salah satu syarat material semikonduktor fotokatalis yang baik adalah memiliki luas permukaan padatan yang luas sehingga penyerapan foton akan lebih maksimal pada saat diaplikasikan sebagai fotokatalis. Ukuran pori pada material fotokatalis tidak boleh terlalu besar ataupun terlalu kecil. Apabila pori material fotokatalis terlalu kecil maka penambahan luas permukaan semikonduktor akan kecil pula, begitu pula apabila pori terlalu besar maka semikonduktor akan bersifat rapuh dan tidak stabil terhadap perlakuan selama aplikasi.

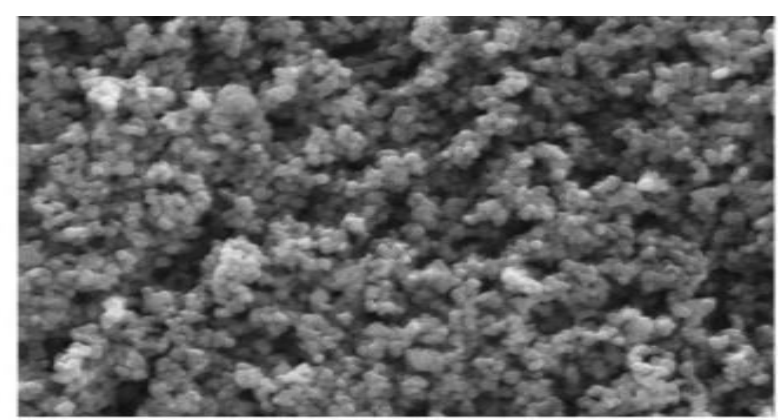

(b)

Gambar 3. Morfologi Permukaan material fotokatalis (a) $\mathrm{TiO}_{2}$ Undoped (b) $\mathrm{N} / \mathrm{TiO}_{2}$ $5 \%(b / b)$ 
Berdasarkan Gambar 3. dapat dilihat bahwa morfologi dari $\mathrm{TiO}_{2}$ undoped dan $\mathrm{N} / \mathrm{TiO}_{2} 5 \%(\mathrm{~b} / \mathrm{b})$ cukup homogen dan seragam. Disamping itu, dapat dilihat juga bahwa morfologi permukaan pada $\mathrm{N} / \mathrm{TiO}_{2}$
5\% (b/b)lebih teratur dan halus daripada $\mathrm{TiO}_{2}$ undoped. Sedangkan untuk unsur yang ada pada $\mathrm{TiO}_{2}$ undoped dan $\mathrm{N} / \mathrm{TiO}_{2}$ 5\% (b/b) dapat dilihat pada Tabel 3.

Tabel 3. Jumlah (\%) unsur yang berada pada permukaan $\mathrm{TiO}_{2}$ dan $\mathrm{N} / \mathrm{TiO}_{2} 5 \%(\mathrm{~b} / \mathrm{b})$

\begin{tabular}{|c|c|c|c|}
\hline Material & Element & $\operatorname{Mass}(\%)$ & $\operatorname{Atom}(\%)$ \\
\hline \multirow[t]{2}{*}{$\mathrm{TiO}_{2}$} & $\mathrm{OK}$ & 38,95 & 65,62 \\
\hline & $\mathrm{Ti} \quad \mathrm{K}$ & 61,05 & 34,38 \\
\hline \multirow[t]{4}{*}{$\mathrm{N} / \mathrm{TiO}_{2} 5 \%(\mathrm{~b} / \mathrm{b})$} & $\mathrm{O} \mathrm{K}$ & 46,29 & 51,78 \\
\hline & $\mathrm{Ti} \mathrm{K}$ & 28,41 & 10,62 \\
\hline & $\mathrm{C} \mathrm{K}$ & 24,92 & 37,12 \\
\hline & N K & 0,38 & 0,49 \\
\hline
\end{tabular}

Berdasarkan Tabel 3 dapat dilihat bahwa unsur Ti mempunyai jumlah yang besar dalam kisi kristal $\mathrm{TiO}_{2}$ yaitu sebesar $61,05 \%$. Jumlah unsur kedua yang mempunyai jumlah yang besar adalah unsur $\mathrm{O}$ sebesar $38,95 \%$. Hal ini mengindikasikan bahwa pada kristal $\mathrm{TiO}_{2}$ hanya memiliki komponen $\mathrm{Ti}$ dan $\mathrm{O}$ sedangkan pada $\mathrm{N} / \mathrm{TiO}_{2} 5 \%(\mathrm{~b} / \mathrm{b})$, unsur $\mathrm{Ti}$ mengalami penurunan menjadi $28,41 \%$. Hal ini mengindikasikan bahwa kristal $\mathrm{TiO}_{2}$ telah dirusak oleh keberadaan Urea. Hal ini dibuktikan dengan adanya unsur $\mathrm{N}$ dan $\mathrm{C}$ yang terdeteksi, sehingga dapat disimpulkan bahwa $\mathrm{N}$ telah masuk ke dalam kisi kristal $\mathrm{TiO}_{2}$. Dari data-data tersebut dapat diketahui bahwa sintesis telah berhasil dilakukan.

Uji Aktivitas Fotokatalis $\mathrm{TiO}_{2}$ undoped dan $\mathrm{N} / \mathrm{TiO}_{2}$ dengan variasi konsentrasi

Aplikasi dilakukan dengan mencampurkan material $\mathrm{TiO}_{2}$ dan $\mathrm{N} / \mathrm{TiO}_{2}$ dengan variasi konsentrasi ke dalam limbah pewarna tenun ikat dan dijemur dibawah sinar matahari selama 5 jam. Limbah pewarna tenun ikat berasal dari industri sentra tenun ikat yang berlokasi di Bandar Kidul, Jawa Timur, Indonesia. Limbah pewarna ini umumnya hanya dibuang ke selokan sehingga mencemari lingkungan daerah sekitar.

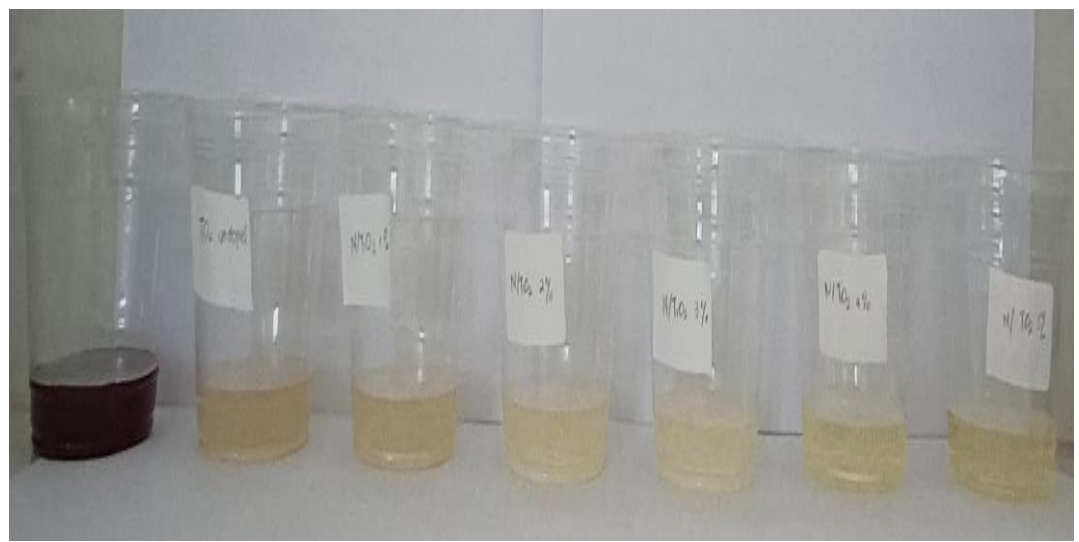

Gambar 4. Aplikasi $\mathrm{TiO}_{2}$ dan $\mathrm{N} / \mathrm{TiO}_{2}$ dengan variasi konsentrasi pada limbah tenun ikat (dari kiri ke kanan : Larutan Limbah tenun ikat, Larutan Limbah tenun ikat $+\mathrm{TiO}_{2}$ undoped, Larutan limbah tenun ikat $+\mathrm{N} / \mathrm{TiO}_{2}$ 1\%(b/b), Larutan Limbah tenun 
ikat $+\mathrm{N} / \mathrm{TiO}_{2} 2 \%(\mathrm{~b} / \mathrm{b})$, Larutan Limbah Tenun Ikat+N/TiO 2 3\%(b/b), Larutan Limbah Tenun Ikat+N/TiO $4 \%(b / b)$, Larutan Limbah Tenun Ikat+N/TiO $5 \%(b / b))$

Material fotokatalis semikonduktor memiliki daya oksidasi yang sangat kuat apabila diaktifkan dengan cahaya matahari. Hal ini dikarenakan untuk mengaktifkan katalis $\mathrm{TiO}_{2}$ dibutuhkan energi foton dengan panjang gelombang yang kecil. Aktivitas fotokatalis ini dapat menyebabkan terjadinya fotooksidasi dan fotoreduksi sehingga terjadi eksitasi elektron dari pita valensi ke pita konduksi. Pita konduksi menyebabkan adanya kekosongan atau hole yag selanjutnya bereaksi dengan $\mathrm{H}_{2} \mathrm{O}$ dalam larutan dan membentuk radikal hidroksil yang dapat mendegradasi senyawa organik menjadi $\mathrm{CO}_{2}$ dan $\mathrm{H}_{2} \mathrm{O}$ (Tussa'adah, 2015). Berdasarkan hasil aplikasi (Gambar 4) dapat disimpulkan bahwa penambahan urea hingga $5 \%(\mathrm{~b} / \mathrm{b})$ terhadap sintesis $\mathrm{N} / \mathrm{TiO}_{2}$ dapat menjernihkan limbah pewarna tenun ikat, meskipun kejernihan limbah kurang maksimal tetapi berdasarkan hasil tersebut dapat diketahui bahwa semakin besar konsentrasi urea yang ditambahkan maka dapat menjernihkan limbah tenun ikat semakin jernih, hal ini sejalan dengan hasil karakterisasi dari material hasil sintesis yaitu material dengan fotoaktivitas paling optimum yaitu pada material $\mathrm{N} / \mathrm{TiO}_{2}$ $5 \%(\mathrm{~b} / \mathrm{b})$.

\section{Kesimpulan}

Berdasarkan penelitian yang telah dilakukan dapat disimpulkan bahwa :

\section{Daftar Pustaka}

Abazović, Nadica D., Luciana Mirenghi, Ivana A. Janković, Nataša Bibić, Daniela V. Šojić, Biljana F. Abramović, and Mirjana I. Čomor. 2009 . "Synthesis and Characterization of Rutile $\mathrm{TiO} 2$ Nanopowders Doped with Iron Ions." Nanoscale Research Letters 4(6):518-25.
1. Semakin besar konsentrasi urea yang ditambahkan maka ukuran kristal yang dihasilkan juga semakin kecil, kecuali pada konsentrasi 3\% (b/b) dan 4\%(b/b).

2. Semakin besar urea yang ditambahkan maka band gap yang dihasilkan akan semakin kecil. Berdasarkan hasil DR-UV dapat diketahui bahwa band gap paling kecil adalah pada material $\mathrm{N} / \mathrm{TiO}_{2}$ $5 \%(\mathrm{~b} / \mathrm{b})$.

3. Hasil SEM EDX menunjukkan bahwa permukaan yang dihasilkan pada $\mathrm{N} / \mathrm{TiO}_{2}$ $5 \%(\mathrm{~b} / \mathrm{b})$ lebih teratur atau homogen apabila dibandingkan dengan $\mathrm{TiO}_{2}$ undoped. Selain itu, diketahui pula bahwa pada sampel $\mathrm{N} / \mathrm{TiO}_{2} 5 \%(\mathrm{~b} / \mathrm{b})$ unsur $\mathrm{N}$ telah berhasil masuk pada kisi kristal $\mathrm{TiO}_{2}$ sebesar $0,49 \%$.

4. Hasil karakterisasi diketahui bahwa material paling optimal yang dihasilkan adalah $\mathrm{N} / \mathrm{TiO}_{2} 5 \%(\mathrm{~b} / \mathrm{b})$, hal ini didukung oleh hasil aplikasi yang membuktikan bahwa material $\quad \mathrm{N} / \mathrm{TiO}_{2} \quad 5 \%(\mathrm{~b} / \mathrm{b})$ menghasilkan larutan limbah yang paling jernih apabila dibandingkan dengan material lainnya.

\section{Ucapan Terima Kasih}

Penulis mengucapkan terima kasih kepada UNISKA-Kediri melalui LPPM UNISKA Kediri atas bantuan dana hibah internal tahun 2019 yang telah diberikan.

Agustina, Tuty Emilia, Ahmad Bustomi, and Jantan Manalaoon. 2016. "Pengaruh Konsentrasi TiO2 Dan Konsentrasi Limbah Pada Proses Pengolahan Limbah Pewarna Sintetik Procion Red Dengan Metode UV/Fenton/TiO2." Jurnal Teknik Kimia 22(1):65-72.

Araoyinbo, Alaba Oladeji, Moch Mustafa 
Al Bakri Abdullah, Mohd Arif Anuar Mohd Salleh, Nurul Nadia Abdul Aziz, and Azwan Iskandar Azmi. 2018. "Phase Study of Titanium Dioxide Nanoparticle Prepared via Sol-Gel Process." in IOP Conference Series.

Condro, Novita, Bing Bedjo $\mathrm{T}$, and Baskoro Banindro. 2014. "Perancangan Buku Tenun Ikat Bandar Kidul Kediri." Jurnal DKV Adiwarna 6.

Garcia, Christian G., André S. Polo, and Neyde Y. Murakami Iha. 2003. "Photoelectrochemical Solar Cell Using Extract of Eugenia Jambolana Lam as a Natural Sensitizer." Anais Da Academia Brasileira de Ciencias 75(2):163-65.

Hoffman, Michael R., Scot T. Martin, Wonyong Choi, and W. Bahnemann. 2013. "Environmental Applications of Photocatalysis." Chemical Reviews 71:35-66.

$\mathrm{Hu}$, Lanying, Hongwei Song, Guohui Pan, Bin Yan, Ruifei Qin, Qilin Dai, Libo Fan, Suwen Li, and Xue Bai. 2007.

"Photoluminescence

Properties of Samarium-Doped $\mathrm{TiO} 2$ Semiconductor Nanocrystalline Powders." Journal of Luminescence 127(2):371-76.

Irie, Hiroshi, Yuka Watanabe, and Kazuhito Hashimoto. 2003. "Nitrogen-Concentration

Dependence on Photocatalytic Activity of TiO 2 - x N x Powders." J.Phys.Chem 5483-86.

Kusumawardani, Cahyorini. 2009. "Titanium Dioksida Terdoping Nitrogen : Kajian Tentang Sintesis , Karakteristik Dan Aplikasinya." Pp. 124-33 in Prosiding Seminar Nasional Penelitian, Pendidikan dan Penerapan MIPA, Fakultas MIPA, Universitas Negeri Yogyakarta.

Pinna, Francesco. 1998. "Supported Metal Catalysts Preparation."
Catalysis Today 41(1-3):129-37.

Poluakan, Michelle, Audy Wuntu, and Meiske S. Sangi. 2015. "Aktivitas Fotokatalitik TiO2 - Karbon Aktif Dan TiO2 - Zeolit Pada Fotodegradasi Zat Warna Remazol Yellow." Jurnal MIPA 4(2):137.

Prastiwi, Berlina Rosa. 2017. "Analisis Dampak Material Batik Cap Terhadap Lingkungan (Studi Kasus : Batik Supriyarso Kampung Batik Laweyan)." Universitas Muhammadiyah Surakarta.

Rosanti, Aulia Dewi. 2014. "Pengaruh Variasi Konsentrasi Garam $\mathrm{FeCl} 3.6 \mathrm{H} 2 \mathrm{O}$,Suhu Kalsinasi, Dan PH Terhadap Karakter Fe-TiO2 Yang Disintesis Menggunakan Metode Sol-Gel." Universitas Gadjah Mada.

Sari, Nur Meita. 2014. "Tenun Ikat ATBM Di Home Industry Kurniawan Bandar Kidul Kediri Jawa Timur." Universitas Negeri Yogyakarta.

Sitanggang, Petra Yohana. 2017. "Pengolahan Limbah Tekstil Dan Batik Di Indonesia." Jurnal Teknik Lingkungan 1(12):1-10.

So, C. M., M. Y. Cheng, J. C. Yu, and P. K. Wong. 2002. "Degradation of Azo Dye Procion Red MX-5B by Photocatalytic Oxidation." Chemosphere 46(6):905-12.

Tussa'adah, R. dan Astuti. 2015. "Sintesis Material Fotokatalis $\mathrm{TiO} 2$ Untuk Penjernihan Limbah Tekstil." Jurnal Fisika Unand 4(1):91-96.

Wardhani, Sri, Akhmad Bahari, and M. Misbah Khunur. 2016. "Aktivitas Fotokatalitik Beads TiO2-N/ZeolitKitosan Pada Fotodegradasi Metilen Biru (Kajian Pengembanan, Sumber Sinar Dan Lama Penyinaran)." Journal of Enviromental Engineering and Sustainable Technology 3(2):78-84.

Zaleska, Adriana. 2008. "Doped-TiO2: A

Review." Recent Patents on 
Engineering 2(3):157-64. 